\title{
Education with Gender Justice in the Perspective of the Constitution
}

\author{
Anna Triningsih \\ The Constitutional Court of the Republic of Indonesia \\ Faculty of Law, Esa Unggul University, Indonesia
}

\begin{abstract}
.
The commitment to changing gender relations to a more just and equal direction has been seen since the United Nations (UN) took steps to affirm equal rights between men and women in its 1945 charter and subsequently in 1946 established the Commission on the Status of Women (CSW). Following up on this, Indonesia participated in implementing the contents of the declaration and action program because the affirmation of women's human rights as contained in the Vienna Declaration was in line with the Pancasila ideology, especially the Second principle, Just and Civilized Humanity. The constitutional basis is the 1945 Constitution in Article 27 which guarantees equal position and rights for all citizens: men and women, both before the law and government as well as for decent work and living for humanity. In the context of accelerating the goals of national development, including development in the field of education, towards gender equality and justice in all aspects of life, both in family life and in the life of the nation and state, gender-based education is a strategic choice, although of course it is a viable choice. heavy considering the many obstacles to be faced. Concrete steps that can be taken are formulating gender policies in national education. The objectives to be achieved through this policy include three main points. First, opening up educational opportunities that are more equitable in all majors, types, and levels of education by considering aspects of gender equality. Second, eliminating all forms of gender inequality in departments, vocational fields, or study programs at the secondary and tertiary education levels so as to create gender equality in various fields of professionalism. Third, provide opportunities and opportunities for women to participate optimally in all units and in all stages of educational development, starting from the formulation stage of policies, decision making, program implementation, to the final stage in the form of evaluation.
\end{abstract}

Keywords: Education, Gender Justice, Constitutional Perspective.

\section{Introduction (TNR 14pt., bold)}

The concept of gender differences is often confused with the concept of gender as a social construction by public understanding. Gender differences are indeed different from birth, it is God's full right in determining the sex of humans. It is different with gender differentiation, it occurs through a long process carried out by humans (society) through imaging, giving roles, how to treat and respect both of them. So that the emergence of gender discrimination, namely one of the sexes is neglected for its basic rights, left behind, and experiencing problems of injustice (Mufidah, 2010). 


\section{2nd Global Conference on Women's Studies}

10-12 June 2021

Berlin - Germany

Education is the most strategic means in transforming social and cultural values that develop in society. Where the educational process in transforming these social and cultural values, whether we realize it or not, has participated in developing gender inequality. A gender-biased culture can develop and persist cannot be separated from the educational process from one generation to the next. The emergence of gender inequality in society is a relay from one generation to the next through an education process that is not based on justice and gender equality (Ribut, 2015). Therefore, there is a need for an effort to open up public insight and awareness of the importance of gender equality and justice as one of the important elements to form a civil society order, namely a just and humane society.

The field of education is one of the keys to the realization of gender justice in society, where education is a tool to transfer community norms, knowledge and abilities. In other words, educational institutions are formal means for socializing as well as transferring values and norms prevailing in society, including gender values and norms (Mursidah, 2013).

This is in line with one of the goals of the Indonesian state, which is to educate the nation's life which is emphasized in its constitutional basis, namely Article 27 of the 1945 Constitution which guarantees equality of position and rights for all citizens, both men and women, both before the law and before the law. government as well as for work and a decent living for humanity, as well as Article 31 of the 1945 Constitution which explains the education that every citizen has the right to take, regarding the obligation to attend basic education, the state's obligation to finance education and educate the nation through education.

\section{Research Methods}

This research is a library research (library research). Through literature sources obtained from laws and regulations and other relevant sources, a study was conducted to describe gender equality education in a constitutional perspective. The data collection technique used is the documentation technique. Considering that the object of this research is a text that demands understanding and appreciation in the present and in the future, the approach that will be used is a hermeneutic approach. Furthermore, the collected data are grouped and arranged systematically, and analyzed critically using deductive and inductive methods. So that the results of this study can produce accurate and accountable conclusions (Mufidah, 2010).

\section{Discussion}

Gender equality is the equality of conditions for men and women to obtain opportunities and their rights as human beings, to be able to play a role and participate in political, legal, economic, socio-cultural, education and national defense and security activities (hankamnas), as well as equality in enjoy the results of this development. Gender equality also includes the elimination of discrimination and structural injustice, both against men and women (Alan, 2015). On this occasion, the child writer discusses (1) the regulation of Gender Equality; (2) Gender Equality in Education; (3) Gender Inequality in Education; and (4) The Importance of Gender Perspective in National Education. 


\section{2nd Global Conference on Women's Studies}

10-12 June 2021

Berlin - Germany

\section{A. The Regulation of Gender Equality}

Justice and equality are the basic ideas, main goals and missions of human civilization to achieve prosperity, build harmonious social and state life, and build quality families. The female population is almost half of the entire population of Indonesia and is a huge potential in achieving progress and a better quality of life. Equal conditions for men and women to obtain opportunities and their rights as human beings to be able to play a role and participate in political, economic, legal, socio-cultural activities, education in defense and national security, as well as equality in enjoying the results of development. Article 27 paragraph (1) of the 1945 Constitution reads: "Every citizen has the same position in law and government and is obliged to uphold the law and the government is no exception" and Article 28 I paragraph (2) contains and affirms the principle of freedom from discrimination. Where the principle of non-discrimination, together with equality before the law and equal protection without discrimination, is a basic and general principle in relation to the protection of human rights. Moreover, Article $28 \mathrm{H}$ paragraph (2) of the 1945 Constitution also guarantees the right to facilities and special treatment to obtain equal opportunities and benefits in order to achieve equality and justice. This convenience and special treatment is part of a corrective and temporary measure, that is, until equality and justice are achieved (Tati, 2010).

Therefore, every citizen, both women and men without exception, has the same responsibility to carry out the purpose of life in the nation and state. Based on the constitutional basis, the 1945 Constitution has guaranteed equality of position between women and men. The implementation of these provisions is contained in several laws and regulations, including Law Number 7 of 1994 concerning the Ratification of the Convention on the Elimination of All Formes of Discrimination Against Women; Law Number 34 of 1999 concerning Human Rights. Article 48 states that women have the right to obtain education in accordance with predetermined requirements, and Article 60 paragraph (1) states that every child has the right to receive education and teaching in the context of personal development in accordance with their interests, talents and intelligence level; Law Number 39 of 1999 concerning Human Rights, which specifically also regulates women's rights; and Law Number 23 of 2004 concerning Elimination of Domestic Violence.

\section{B. Gender Equality in Education}

Gender Equality is the equality of conditions and positions for women and men to have the opportunity to access, participate, control, and obtain development benefits in all areas of life; Gender justice is a condition and treatment that describes the equality of rights and obligations of women and men as individuals, family members, communities and citizens. It is undeniable, historically there has been male domination in all walks of life throughout the ages, where women are considered inferior to men. From this arose the doctrine of inequality between men and women (Ashgar, 1994).

Education is a conscious and planned effort to create a learning atmosphere and learning process so that students actively develop their potential to have religious spiritual strength, self-control, personality, intelligence, noble character, and the skills needed by themselves, the community, nation and state. 2015). This is an affirmation of the importance of education 


\section{2nd Global Conference on Women's Studies}

10-12 June 2021

Berlin - Germany

to change traditional patterns into modern patterns that are more capable of prospering the wider community. This condition also implies the need to improve the quality of learning at each type and level of education.

Education is not only considered and stated as a main element in efforts to educate the nation but also as a product or social construction, thus education also has a role in the formation of gender relations in society. Education must touch the needs and be relevant to the demands of the times, namely the quality of having faith and living in strong devotion, recognizing, living and applying the cultural roots of the nation with broad and comprehensive insight, mastering science and cutting-edge skills, able to anticipate the direction of development, think analytically, open to new things, independent, selective, have high social awareness, and can improve achievement. Women in their education are also directed to obtain these qualifications according to their level of ability and interest (Mohammad, 2003). In other words, gender-oriented educational ideas are needed so that they are able to develop the character of students. Therefore, if in reality education is merely providing skill-based competencies needed by industry, without providing internalized values in the personality of students, then education has experienced disorientation.

To develop society, there are several principles that must be grown in the implementation of emancipatory education (Eti Nurhayati, 2012):

1) Equity, this principle contains the meaning of equality and equality in the use of every opportunity. In the field of education, equal opportunities must be given to small people, women, adults and the elderly, people in remote areas, isolated tribes, ethnic minorities and others.

2) Sustainability, the basic principle of sustainable development according to the World Commission on Environment and Development (1987) that the current generation must meet its needs without sacrificing the ability of future generations to meet the needs of the community. Emancipation education for society must be held continuously between generations.

3) Productivity, education organized by the community must produce the maximum benefit for the progress of the community through investment in human development that allows humans to reach their optimal potential.

4) Empowerment. Empowerment means providing opportunities for individuals to excel actively in every development endeavor as well as community learning efforts in the self-development process, providing opportunities for each member of the community to develop according to their abilities.

Because education aims to build a national order wrapped in the values of intelligence, sensitivity and concern for the life of the nation and state. Education is a strong milestone for alleviating poverty of knowledge, solving the problem of ignorance and solving all the problems of the nation that have been happening so far. When women contribute to the world of education.

\section{Gender Inequality in Education}




\section{2nd Global Conference on Women's Studies}

10-12 June 2021

Berlin - Germany

Gender differences give birth to gender inequalities both for men and especially for women. This can be seen from the manifestations of existing injustice where the gender inequality includes (Nunuk, 2004):

1) Marginalization of women, means placing or shifting women on the margins. Where women are imaged as weak, lacking or irrational, lacking or not brave, so that they are inappropriate or unable to lead;

2) Society stereotypes against women, namely the standardization of discrimination between women and men. Women and men already have their own proper nature, so they cannot get out of the existing nature.

3) Subordination to women, positioning women and their works as lower than men, causing them to feel they are worthy of being assistants, number two, shadow figures, and not daring to show their abilities as individuals. Where men think women are not able to think like their size, so they are always worried when giving women heavy work;

4) Double burden on women, where the work given to women is longer in the public sector, they still have household responsibilities that cannot be done if they are given to men, because women who work are handed over to housemaids even though they are both female.

5) Violence against women can be in the form of psychological violence, such as harassment, requests for sex in public places, jokes that harass women's sex, physical violence, such as murder, rape, abuse of women and so on.

Gender inequality as mentioned above is often very difficult to argue for due to various reasons as follows: the general assumption that gender activities/roles are natural, so that when we question it, it is considered as against nature or belief, which is of course very private. Some women themselves are not aware of the existence of gender inequality because they have long adopted the ingrained patriarchal ideology. They are willing to surrender to the ideology that places them as second people, and accept violence or oppression as their obligation or nature. Many women are willing and enjoy the position as a peddler or object of patriarchal desire.

This also has an impact on education, where gender inequality in education is in the form of gaps in obtaining consistent opportunities at each type and level of education. Women tend to have smaller educational opportunities than men, the higher the level of education, the wider the gap. This gap in turn leads to differences in the average earnings of men and women. Even with the same educational background, the average income of the female workforce is consistently lower than that of the male workforce. There are several causes of inequality in education, including:

1) Gender Biased Curriculum

The implementation of the educational curriculum itself is contained in the textbooks used in schools. The reality is that in the education curriculum (religious or general) there are still many things that highlight that men are in the public sector while women are in the domestic sector. In other words, the curriculum that contains teaching materials for students is not yet gender-neutral in terms of pictures or sentence illustrations used in the explanation of the material. The gender-biased 


\section{2nd Global Conference on Women's Studies}

10-12 June 2021

Berlin - Germany

curriculum contains two things, namely: a. Educational curriculum in theory in the material provided; and $\mathrm{b}$. The curriculum is given in the form of activities or practices.

2) Discriminatory School Policy

The policies taken by the education authorities towards male and female students often harm one of them. But the most disadvantaged are female students, such as the point of view that distinguishes female and male maps. First, the field of study accepted by men is more about the allocation of time and free opportunities. Second, being outside (community and environment) lacks a place and welcome, meanwhile regulations and policies aimed at women have limited their work outside so that they lack information and activities (Agnes, 2015). Discrimination treatment in the learning process is rooted in the conventional paradigm which views girls as inferior to boys in various life participations.

3) Stigmatization of Disciplines

Stigmatization of differences in scientific disciplines becomes a culture in society. This has resulted in discrimination against women's education. The discrimination is caused by several factors, including: Economic Factors, Education Facilities Factors, Social Factors and Gender Role Distribution Factors. Where these factors have an impact on the emergence of problems (Eti Nurhayati, 2012):

a) Male dominance in decision making.

b) Because women's education is inadequate and lacks skills, many wives whose lives depend on their husbands tend to apply a patriarchal system.

c) The high level of underage marriage, especially for women, as a result, many underage marriages and divorces occur because their age shows that they are not ready to marry

d) Due to lack of education, they are less able to foster a family psychologically and family health.

Gender inequality can also be observed in terms of the content of textbooks. Most textbooks, especially Language and Literature, Social Studies, Civics, Physical Education, Arts and the like, which discuss the position of women in society tend to still adhere to gender-biased values. Women in these books are still placed in domestic roles, on the other hand, men are positioned in public roles (productive roles). Thus the contents of these books still acknowledge the existence of strict spatial segregation between men and women; men in the public sphere, while women in the domestic sphere. Curriculum and subject matter that do not refer to the principles of gender equality and justice will cause women to still not have the mentality as productive citizens of society.

The same disparity is also seen in the Educational Personnel Education Institutions (LPTK). Control over education policy is dominated by men, considering that men are more in strategic positions in education management, especially in structural positions, starting from the central level to the lowest level. This causes the participation of women in the decision-making process in the field of education is still relatively low. As a result, a number of policies in education are seen as not yet gender sensitive. 


\section{2nd Global Conference on Women's Studies}

10-12 June 2021

Berlin - Germany

\section{The Importance of Gender Perspective in National Education}

Law Number 34 of 1999 concerning Human Rights in Article 48 states that women have the right to obtain education and teaching in accordance with the requirements stipulated by Article 60 paragraph (10) stating that every child has the right to receive education and teaching in the context of personal development in accordance with with their interests, talents and levels of intelligence. Law Number 23 of 2004 concerning the Elimination of Domestic Violence, namely Article 3, states the principles and objectives for respecting human rights, justice and gender equality, non-discrimination and protection of victims. The Presidential Instruction Number 9 of 2000 concerning Gender Mainstreaming in National Development, aims to implement gender mainstreaming for the implementation of planning, preparation, monitoring and evaluation of national development program policies with a gender perspective in accordance with their respective duties and functions as well as authorities. Gender mainstreaming is carried out, among others, through gender analysis and communication, information, information and education efforts and government institutions at the central and regional levels.

In the context of accelerating national development goals, including the development of the field of education, towards gender equality and justice in all aspects of life, both in family life and in the life of the nation and state, gender-oriented education is a strategic choice, although of course it is a good choice. difficult considering the many obstacles that will be faced. The objectives of education with a gender perspective include (Bappenas, 2006):

1) Having equal access to education, for example boys and girls have the same right to be able to attend education up to a certain level of formal education, of course it is unfair, if in today's global era education is secondary to women, especially if girls have the ability. The idea that women are workers in the domestic sector (household work) so that they do not need to be given higher formal education is a wrong idea.

2) Equal obligations, for example, a man and a woman both have the obligation to seek knowledge. In line with the hadith according to science, it is an obligation for every Muslim male and Muslim female.

3) Equality of position and role, for example, both men and women have the same position as subjects or actors of development. The position of men and women both as subjects of development has the same role in planning, implementing, monitoring and enjoying the results of development. Finally, it has to do with equality of opportunity.

Concrete steps that need to be taken immediately are to formulate gender policies in national education. At least the objectives to be achieved through the policy include three main things. First, to open up more equitable educational opportunities in all majors, types, and levels of education by taking into account aspects of gender equality. Second, eliminating all forms of gender inequality in majors, vocational fields, or study programs at the secondary and higher education levels so as to realize gender equality in various fields of professional expertise. Third, providing opportunities and opportunities for women to participate optimally in all units and in all stages of education development, starting from the policy formulation stage, decision making, program implementation, to the final stage in the form of evaluation. 


\section{2nd Global Conference on Women's Studies}

10-12 June 2021

Berlin - Germany

In order for this goal to be realized optimally, it is necessary to first improve the balance of the number of teachers and education personnel on the basis of gender in all fields and at all levels of education. Next, develop a gender-sensitive approach to the learning process through coaching and training teachers, school principals, and education supervisors. Likewise, it is necessary to increase women's participation, especially at the decision-making level in all national education management units.

Next, all writers of reading materials and those in charge of curriculum development are given orientation on educational policies with the perspective of gender equality and justice so that it is hoped that there will be no more gender-biased curriculum and school reading books. However, the most important priority is to provide the widest opportunity for women to enter all types and levels of education through the provision of scholarships or subsidies, especially for those from underprivileged families, as well as providing affirmative action for women to enter majors or programs. Of course, the study program which has been a male monopoly, of course, the policy is temporary, namely only for a certain period of time, so that a balance in the number of students and students is established according to gender in all types and levels.

\section{Conclusion}

Education is a basic human need, be it formal or informal education, education plays an important role for every human being, be it male or female, because humans have the right to education since they were in the mother's womb, for their future provision in life. in accordance with the mandate of the 1945 Constitution. So it is very unfair if in education there is discrimination against one party who will be harmed by the community in the opportunity to achieve various knowledge in all fields according to individual interests. Therefore, the existence of gender equality in education should be able to help participants in the world of education. To provide welfare to the community as optimally as possible, so that there is no backwardness in morals, knowledge, thinking patterns that result in many gender inequalities in education.

Gender equality is in line with the times, which is supported by the development of science and technology that encourages economic development and the globalization of information that allows women to work and play the same role as men. The level of gender bias occurs in many fields, especially in the field of education, for example, gender roles occur in terms of accessing educational institutions which causes low participation of women.

Education is a very important tool to achieve gender equality in the relationship between men and women, there are still many development policies that are gender biased and seem to ignore the role of women. It can be seen in people's lives that there are still many cultural values and practices that hinder justice and gender equality.

Therefore, it is hoped that future challenges can rebuild education as part of the cultural movement. To ensure the fulfillment of human rights and implementation, where women can move forward together and feel the same treatment as other citizens, namely men because in fact humans are also humans who have the same human rights and with the opening of wider access to education, it is a key to improve empowering women to be able to participate in decision-making in all areas of community life in accordance with the constitutional mandate 


\section{2nd Global Conference on Women's Studies}

10-12 June 2021

Berlin - Germany

\section{Acknowledgment}

The author states that in this study the two writers became the main contributors, each of whom carried out the task proportionally.

\section{References}

Mufidah CH., (2010). Bingkai Sosial Gender: Islam, Strukturasi \& Konstruksi Sosial, UINMaliki Press, Malang.

Ribut Purwo Juono., (2015). Kesetaraan Gender Dalam Pendidikan Islam (Studi Pemikiran Pendidikan Hamka dalam Tafsir al-Azhar), ANALISIS: Jurnal Studi Keislaman, Volume 15 Nomor 1, Juni 2015, hlm. 122.

Tobroni, dkk., (2007). Pendidikan Kewarganegaraan, Demokrasi, HAM, Civil Society, dan Multikulturalisme, Pusat Studi Agama, Politik, dan Masyarakat (PuSAPoM), Malang.

Mursidah., (2013). Pendidikan Berbasis Kesetaraan dan Keadilan Gender, Jurnal Muzawa Volume 5 Nomor 2, Desember 2013, hlm. 278.

Alan Sigit Fibriyanto, (2015). Kesetaraan Gender Dalam Lingkup Organisasi Mahasiswa Universitas Sebelas Maret Surakarta Tahun 2016, Jurnal Analisa Sosiologi, April 2015, Volume 5 Nomor 1.

Tati Krisnawaty, dkk., (2010). Modul Pelatihan Pemenuhan Hak-Hak Konstitusional Warga Negara, Komnas Perempuan Indonesia.

Asghar Ali Engineer., (1994). Hak-Hak Perempuan dalam Islam, terj. Farid Wajidi dan Cici Farkha Assegaf, Lembaga study Pengembangan Perempuan dan Anak, Yogyakarta.

Warni Tune Sumar., (2015). Implementasi Kesetaraan Gender Dalam Bidang Pendidikan, Jurnal Musawa, Volume 7 Nomor 1, Juni 2015, hlm. 161.

Moh.Roqib., (2003). Pendidikan Perempuan, Gama Media, Yogyakarta.

Eti Nurhayati., (2012). Psikologi Perempuan Dalam Berbagai Perspektif, Pustaka Pelajar, Yogyakarta.

Nunuk P. Murniati. (2004). Getar Gender, Indonesia Tera, Magelang.

Agnes Widanti, Fatimah Usman., (2015). Belajar Gender, Analisis: Mengurai Ketimpangan Gender dalam Realitas Masyarakat, JGJ PMII Jateng, Semarang.

Bappenas., (2006). Modul Evaluasi Pelaksanaan Pengarusutamaan Gender Di Sektor Pendidikan, Drektorat Kependudukan dan Pemberdayaan Perempuan Bappenas bekerja sama dengan CIDA mlalui Women's Support Project Phase II. 